\title{
Applying the Principle of "Lesson Study" in Teaching Science
}

\author{
Zanaton Hj Iksan ${ }^{1}$, Siti Nor Aishah Mohd Nor ${ }^{1}$, Siti Nordiyana Mahmud ${ }^{1} \&$ Effandi Zakaria ${ }^{1}$ \\ ${ }^{1}$ Department of Teaching and Learning Innovation, Faculty of Education, Universiti Kebangsaan Malaysia, \\ Malaysia \\ Correspondence: Effandi Zakaria, Department of Teaching and Learning Innovation, Faculty of Education, \\ Universiti Kebangsaan Malaysia, Malaysia. E-mail: effandi@ukm.my
}

Received: November 3, 2013 Accepted: December 18, 2013 Online Published: January 26, 2014

doi:10.5539/ass.v10n4p108 URL: http://dx.doi.org/10.5539/ass.v10n4p108

\begin{abstract}
Lesson Study is a model of professional teacher development aimed at improving teaching and learning process. The Malaysian Ministry of Education had been implementing Lesson Study at the school level gradually. Science program's students at the Faculty of Education are asked to simulate teaching in macro teaching according to their field of specialization. To enhance the development of teaching and learning, lesson study is applied in the chemistry method course. This article aims to discuss the planning and implementation of lesson study in the teaching of chemistry method course.
\end{abstract}

Keyword: macro teaching, micro teaching, teaching and learning, lesson study

\section{Introduction}

Existing teaching method should always be refined and developed in order to guarantee the quality of teaching. Recent studies primarily focus on attitudes, perceptions, and behaviors of students as well as their relationship with students' achievement. Further research is needed to explore the process and implementation of teaching because the development of teaching and learning includes input, process, and output. Thus, the processes that occur during teaching and learning play a big role in developing students' pedagogical skills. Pedagogy is one of the important elements that students enrolled in teaching courses in all education institutions have to understand and master. Pedagogy is a basic knowledge because it involves the methods and principles of teaching. Pedagogy can be defined as a method of teaching that includes skills and abilities in terms of the principles of teaching, classroom management, teaching methods, application of technology, learning styles, and learning and teaching assessment (Sulaiman, 2004). The students can learn all these aspects through Macro Teaching or Micro Teaching. Micro Teaching and Macro Teaching is a simulation activity that introduces students to the process of teaching and learning at trainee teachers' level. Micro Teaching is a 7 to 15 -minute simulation activity that emphasizes specific skills in teaching. Meanwhile, the Macro Teaching is a simulation that involves a 30 to 40-minute simulation teaching session. The Micro and Macro Teaching can be done with various techniques and teaching methods that is appropriate to students, classroom environment, facilities, and time. The goal of the Micro and Macro Teaching is to expose students directly to the teaching and learning process.

Micro Teaching is one of the most important developments in the field of teaching practices. Dwight Allen, the Chief Research and Development in Education, developed this lesson. It was introduced at Stanford University in 1963. Micro Teaching gives trainee teachers the experience and skills similar to those needed in a real teaching situation. Basically, Micro Teaching is a teaching simulation in which the teaching is limited in certain aspects, such as class size, lesson content, and reduced discipline. Portner (1998) stated that trainee teachers are responsible for devising teaching pattern. A usual practice in this chemistry method course is that each student is required to teach by applying experiments, demonstrations, or group work approaches. Before teaching started, he or she needs to prepare individual lesson plans to be used in the teaching process. Two students evaluated the teaching simulation conducted by their peer. Based on our observation, students appeared to experienced difficulties in preparing lesson plans. In terms of teaching, students repeated the same mistakes despite the evaluators' comment and warning. Thus, researcher felt that teaching each student through a current simulated teaching method was not satisfactory or effective. Hiebert et al. (2002) emphasized that continuous professional development of teachers should be done through collaboration between teachers and should be shared and documented. The collaborative efforts can be analyzed and developed, thus it can become reference in the future. 


\section{Lesson Study Approach}

Lesson Study approach is another method to transform practical knowledge of ideas to professional knowledge of teachers in the process of continuous professional development of teachers. Lesson Study is a translation of the Japanese word "Jugyokenkyu". "Jugyo" means teaching and "kenkyu" means the study. "Jugyokenkyu" covers most of the instructional improvement strategies, characteristics shared by a group of teachers through observation during the teaching session conducted and subsequently collaborate to analyze data (Lewis, Perry, \& Murata, 2006). The data obtained from this study will be shared during the discussion after the lesson, which will allow students to reflect on their teaching and learning (Lewis, 2002). This will enable teachers to work in collaboration to raise the quality of their teaching and enrich students' learning experiences. The features of the Lesson Study have contributed to the expansion of teachers' knowledge about the purpose of collaborative discussion and assessment. Lesson Study practice should start early on while the teachers are still in the pre-service. Knowledge to learn the method of teaching is the knowledge of how to learn from the experience of teaching in the classroom (Hiebert et al., 2007). Teachers' preparation should focus on how to build professional knowledge (Korthagen et al., 2006) while focusing largely on students' achievement. Lesson Study provides opportunities for teachers to observe students' participation in the classroom. Sumar et al. (2007) demonstrated the role of Lesson Study in the development of teachers' knowledge about teaching.

Lesson Study involves an in-depth focus on the process. This approach is done in a group, and the activities are carried out with the cooperation of every member of a group. This collaborative effort reflects professional teacher development process that is capable of forming an effective teacher community (Cheng \& Yee, 2012). In fact, this approach can improve teaching to ensure that teachers understand the concept of teaching and learning. In addition, the pedagogical aspects can also be evaluated and identified with an aim to improve teaching. Therefore, this study will apply the concept of Lesson Study in the implementation of the Macro Teaching of chemistry courses. Indeed, when applying Lesson study in Macro Teaching, the performance of teaching skills to students can be measured in detail based on the direct involvement of teachers and students in teaching and learning process (Solomon et al., 2011).

\section{Literature of Lesson Study}

Lesson Study has been implemented by the Japanese education system since 1900's. However, Stigler and Hiebert described Lesson Study extensively in 1999 in their book "The Teaching Gap" (Hock \& Sam, 2010). Lesson Study is an approach used to conduct the research on teaching in the classroom. This approach is able to explore the development of more meaningful teaching because it emphasizes the teaching process. The exploration of the teaching process is in the form of inquiry investigation (Chassels \& Melville, 2009) and systematically through the observation of teaching (Fernandez, 2002). Lesson Study is a continuation of collaborative teaching methods and has its own characteristics (Daipi, 2009). Lesson Study can enhance teachers' learning experience as well as improve their teaching. Teacher learning experiences include teachers' knowledge of the content of the lesson (content knowledge) and knowledge of teaching methods (pedagogical knowledge), which should be built and derived from observation and reflection activities of teaching practices (Dotger et al., 2012; Lewis, 2008; Post \& Varoz, 2008). It also does not marginalize the importance of students' learning in the teaching process. The evaluation and reflection of each lesson is not only on teachers but also focuses on the development of student learning. Teachers observe learning ability and intelligence of students (Cheng \& Yee, 2012; Lewis, 2008). This helps teachers plan lessons carefully and meet the students' needs. In addition, the Lesson Study approach enhance creativity and critical thinking of trainee teachers (Ong et al., 2010), particularly when analyzing in-depth lessons, stimulating innovation, and reforming teaching and learning to find solutions to a problem and to expand understanding skills as well as the ability of teachers and students. Lesson Study can be implemented in various ways to suit the teachers, students, and the environment while meeting the criteria in Lesson Study cycle, as shown in Figure 2. 


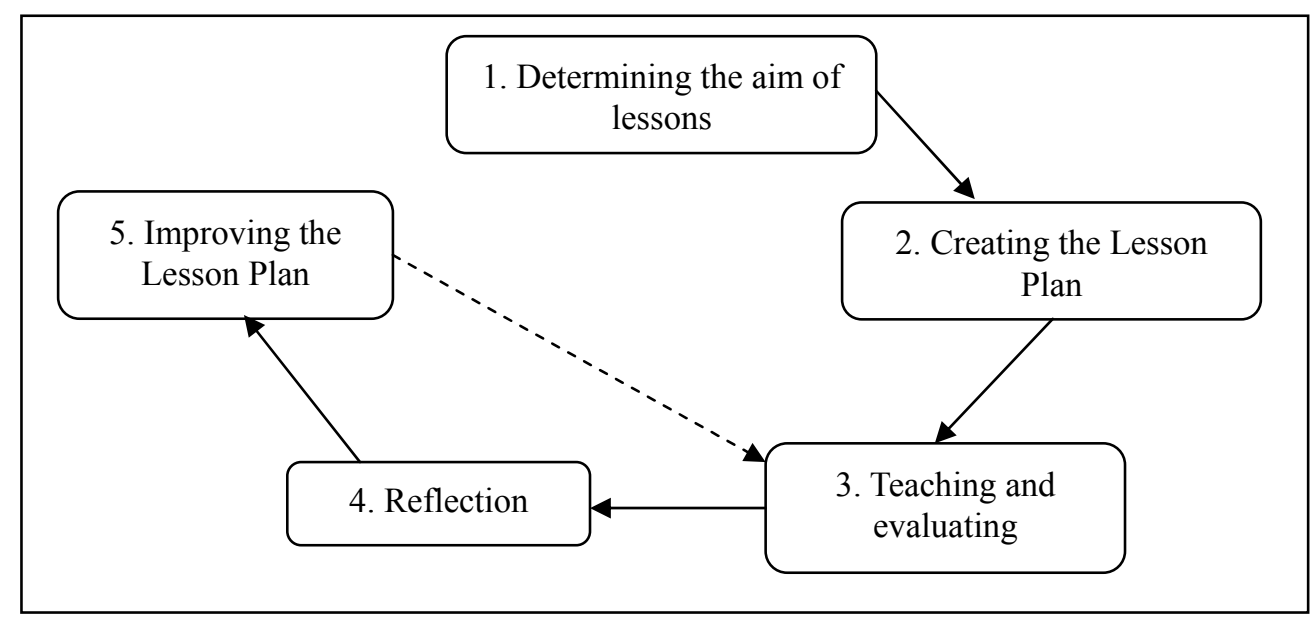

Figure 2. Cycle of lesson study

Lesson Study implementation involves several teachers teaching sessions. Uniquely, the teachers work together to determine the objective of each teaching session. The first step in the Lesson Study involves teachers' discussion to determine appropriate learning objectives with targeted students. The teaching objective should be reasonable as students need to understand the concept and teach effectively. In the second step, teachers are asked to build a complete Lesson Plan for teaching together (Lewis, 2008; Post \& Varoz, 2008; Teacher Education Division of the Ministry of Education, 2011) based on long-term judgments about student learning. Lesson Plan contains detailed information about different aspects of each lesson to be carried out (Fernandez, 2002). Cooperation in the preparation of this Lesson Plan is expected to generate more thoughtful ideas. In the third step, a teacher will implement teaching in a simulation classroom based on the proposed Lesson Plan. Another teacher will monitor and evaluate the teaching (Lewis, 2008; Post \& Varoz, 2008). Both are expected to understand the subject matter taught, as they will develop a Lesson Plan. Therefore, the observation of the students responses is based on observations protocol then the results is recorded (Fernandez \& Robinson, 2006). Deep observations will provide detailed feedback to stimulate the teacher to understand their students' learning better (Cheng \& Yee, 2012). After completing the lesson, the teacher will reflect on the teaching and learning and discuss the strengths and weaknesses of teaching during the process of teaching (Teacher Education Division of the Ministry of Education, 2011). As such, the Lesson Plan can be improved based on the reflections, which can be used to identify weaknesses in the operation of learning (Marble, 2007). Next, the second lesson can follow the improved Lesson Plans. Indeed, during the second lesson, the teacher can try to modify the thoughts of students who previously adopted the wrong concept of learning (Cheng \& Yee, 2012).

\section{Implementation of Lesson Study in Macro Teaching}

The Macro Teaching in methods courses involves individualized learning that starts from building Teaching Plan, reflecting upon the process of teaching, and improving Lesson Plan. The weaknesses observed during the teaching simulation performed by peers after approval ratings from evaluator and lecturers should be a lesson to improve for themselves and other students as well.

Lesson Study innovation in Macro Teaching of Chemistry teaching courses can be done as shown in Figure 3. This innovation will be able to assist teachers in building their basic skills through quality teaching in the classroom (Sulaiman et al., 2011). 


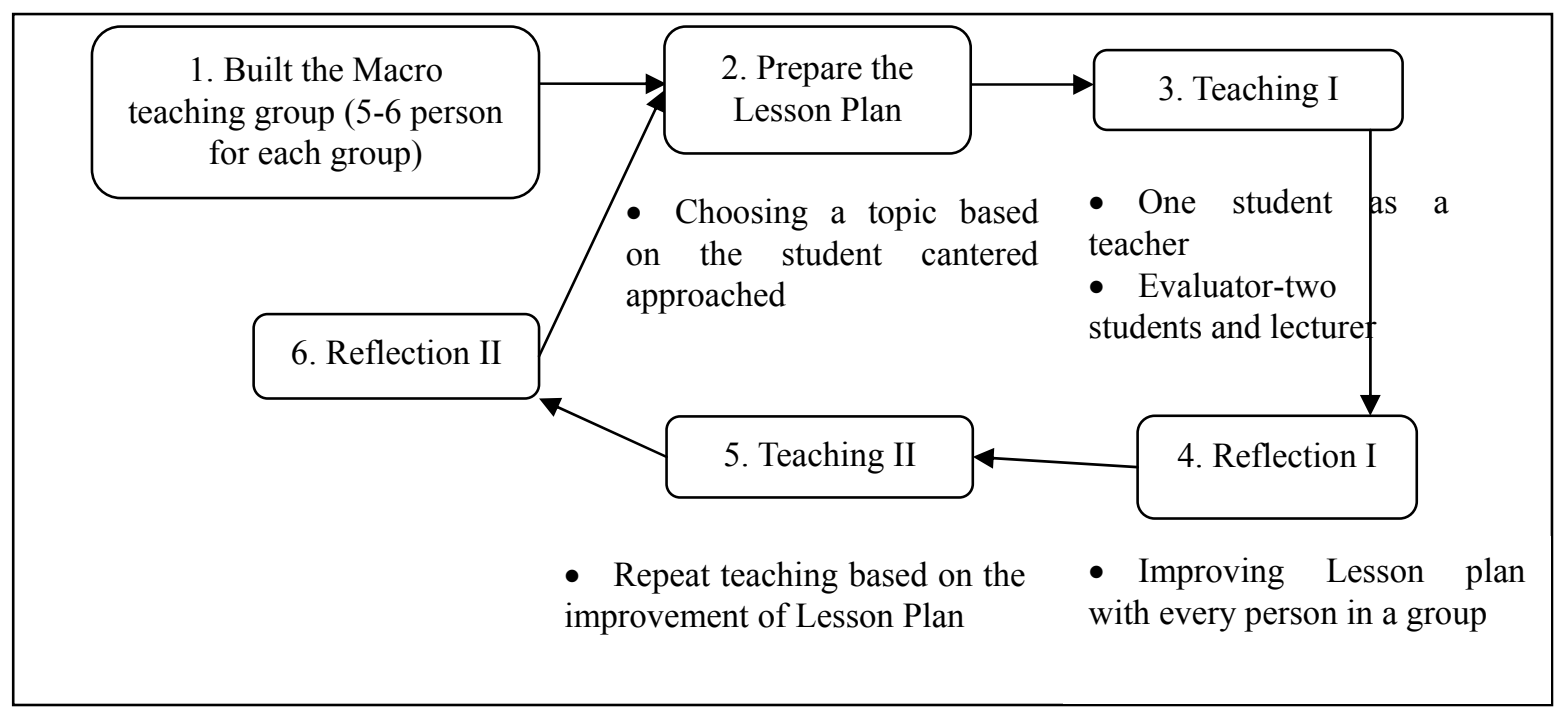

Figure 3. Model of the integration of macro teaching and lesson study (MTLS)

Lesson Study integration in Macro Learning begins with the formation of the group. Students work in groups to produce lesson plans and engage in teaching followed by reflection. Subsequently, they teach again followed by repetition and reflection. Finally, the improved Lesson Plan will be submitted as an assignment.

\subsection{Forming a Group}

The number of students in class is 27 forming five groups comprising 5 to 6 students per group. Groups will be formed at random because all students have the same features. Each student in a group will have a task, and Figure 4 shows the distribution of tasks and teaching methods for each student that will be used during class.

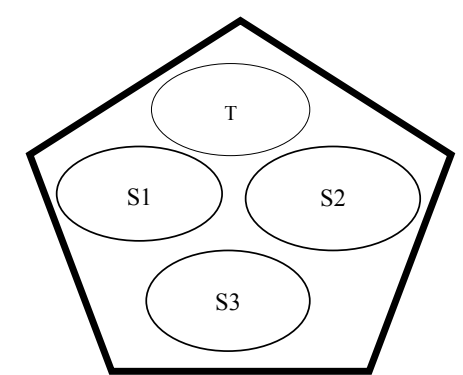

G1: Experiment

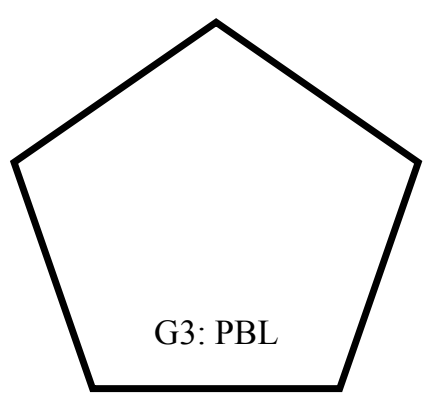

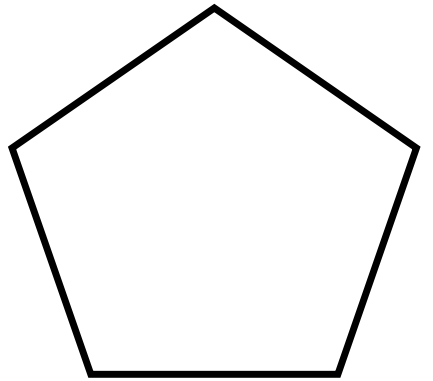

G2: Demonstration

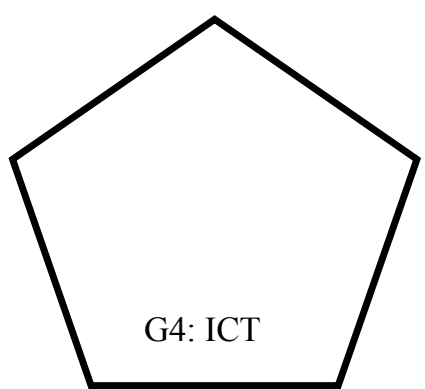

T-teacher

S1-evaluator 1 thinking skills

$\mathrm{S} 2$-evaluator 2-values

S3-evaluator 3-questioning

Figure 4. Quotation of a teaching method and students' task

Each group should prepare according to the given teaching methods. Figure 4 shows that the first group will be teaching using experiment, the second group will use demonstration, the third group will use the problem based Learning (PBL), and group 4 will use ICT approaches. Each team member will be given an individual task. One of them will be teacher and teach based on the lesson plan that they will built together while other students will 
evaluate their classmate's teaching.

\subsection{Preparation of Lesson Plan}

Each group should prepare lesson plans collaboratively. Lesson Plan prepared jointly would allow the members of the group to share ideas while learning various skills that will be applied. The Lesson Plan should be prepared in reference to the syllabus, textbooks, and books.

\subsection{Teaching $I$}

After completing the Lesson Plan, one student from each group will engage in simulated teaching in the classroom. Simulated teaching will resemble the real teaching; with one student teaching while other students pretending to be the students. Teachers will use an audio recording (MP3) to record the development of teaching dialogue. In addition, audio recording is also done to evaluate the entire teaching process. The members of the group and lecturer will review the teaching process. Evaluators will play different roles. Figure 4 shows that the role of evaluator 1 is to assess the thinking skills while evaluators 2 and 3 will assess the questioning techniques used by the teacher. Evaluation will be done by referring to the skills that have been planned in the lesson and see how certain skills applied in the teaching process. This means that each evaluator will refer to teachers' Lesson Plans during the evaluation. Evaluation of teaching will be done through the development of teaching verbatim. Teaching verbatim will be available via audio recording that is transcribed by each team member.

\subsection{Reflection I}

Upon the completion of the lesson, lecturers and students will comment on the teaching and learning processed based on the Lesson Plan. The discussion will begin with teacher's reflection to see how many teaching objectives have been achieved. The evaluator will provide further reflections. Evaluator will comment by linking the planned skills with those that have actually been implemented. Evaluators will also look at specific skills that arise during the teaching. Finally, another participant who will serve as a student will be given the opportunity to evaluate the entire teaching and learning process. All comments will be recorded to improve the Lesson Plan. The improved lesson plans will be used to teach the next class.

\subsection{Teaching $I I$}

The second teaching and lesson plan will be using the same topic but will be improved based on the comments and observations made by the members of the group. Additional teaching lessons will increase students' confidence, assuring that they will not commit the same offenses as they did in the first lesson. Other group members will equally benefit from repeating this lesson.

\subsection{Reflection II}

Repeated teaching will be evaluated by the lecturer and other students to further improve the quality of teaching. New comments will be recorded by the group and included in the improved lesson plan. Finally, the improved lesson plans should be consolidated and submitted as an assignment.

\section{Conclusion}

Macro teaching and Lesson Study teaching method that was recently introduced has not been practiced by the Faculty of Education at Universiti Kebangsaan Malaysia. Such innovation in Macro Teaching known as MTLS model will allow future students to implement new teaching methods more effectively. Through this direct exposure, teaching experience and learning process could help build an effective learning atmosphere for the students. In addition, the students will work more closely with each other that promote cooperation and tolerance in generating ideas. The goals of Macro Teaching and the benefit of implementing Lesson Study can be achieved simultaneously if the students and lecturers are committed to this MTLS model.

\section{References}

Chassels, C., \& Melville, W. (2009). Collaborative, Reflective, and Iterative Japanese Lesson Study in an Initial Teacher Education Program: Benefits and Challenges. Canadian Journal Education, 32(4), 734-763.

Cheng, L. P., \& Yee, L. P. (2012). A Singapore Case of Lesson Study. Mathematics Educator, 21(2), 34-57.

Daipi, M. N. (2009). Kajian Pengajaran: Lesson Study. Retrieved April 25, 2012, from http://www.slideshare.net/mohamednaim/lesson-study-kajian-pengajaran

Dotger, S., Barry, D., Wiles, J., Benevento, E., Brzozowski, F., Hurtado-Gonzales, J., ... Wisner, E. (2012). Developing Graduate Students' Knowledge of Hardy-Weinberg Equilibrium through Lesson Study. Journal of College Science Teaching, 2(1), 40-44. 
Fenandez, C. (2002). Learning from Japanese Approaches to Professional Development the Case of Lesson Study. Journal of Teacher Education, 53(5), 393-405. http://dx.doi.org/10.1177/002248702237394

Fenandez, M. L., \& Robinson, M. (2006). Prospective Teachers' Perspectives on Microteaching Lesson Study. Education, 127(2), 203-215.

Hendayana, S., Karim, M. A., \& Sukirman. (Eds.). (2007). Lesson Study: Strategy to enhance teachers' professionalism (Experience from IMSTEP-JICA). Bandung, FPMIPA UPI and JICA.

Hiebert, J. A., Morris, A. K., Berk, D., \& Jansen, A. (2007). Preparing teachers to learn from teaching. Journal of Teacher Education, 58, 47-61. http://dx.doi.org/10.1177/0022487106295726

Hiebert, J., Gallimore, R., \& Stigler, R. W. (2002). A Knowledge Base for The Teaching Profession: What Would It Look Like and How Can We Get One? Educational Researcher, 31, 3-15. http://dx.doi.org/10.3102/0013189X031005003

Hock, C. U., \& Sam, L. C. (2010). Disseminating and Popularising Lesson Study in Malaysia and Southeast Asia. APEID Hiroshima Seminar. Current Status and Issues on Lesson Study in Asia and the Pacific Regions, 1-9.

Korthagen, F., Loughran, J., \& Russell, T. (2006). Developing fundamental principles for teacher education programs and practices. Teaching and Teacher Education, 22(8), 1020-1041. http://dx.doi.org/10.1016/j.tate.2006.04.022

Lewis, C. (2002). Does Lesson Study have a future in the United States? Journal of the Nagoya University, Department of Education, 1, 1-23.

Lewis, C. (2008). Lesson Study How Can It Build System-Wide Improvement? Retrieved from http://www.csus.edu/mase/calessonstudy/2008/docs/proceedings/Catherine_Lewis.pdf

Lewis, C., Perry, R., \& Murata, A. (2006). How should research contribute to instructional improvement? The case of lesson study. Educational Researcher, 35(3), 3-12. http://dx.doi.org/10.3102/0013189X035003003

Marble, S. (2007). Inquiring into Teaching: Lesson Study in Elementary Science Methods. Journal of Science Teacher Education, 18(6), 935-953. http://dx.doi.org/10.1007/s10972-007-9071-6

Ong, E. G., Lim, C. S., \& Ghazali, M. (2010). Examining the Changes in Novice and Experienced Mathematics Teachers' Questioning Techniques through the Lesson Study Process. Journal of Science and Mathematics Education in Southeast Asia, 33(1), 86-109.

Post, G., \& Varoz, S. (2008). Lesson-Study Groups with Prospective and Practicing Teachers. Teaching Children Mathematics, 4, 472-478.

Sulaiman, E. (2004). Introduction to Pedagogy. Skudai: Universiti Teknologi Malaysia Publisher.

Sulaiman, M., Ismail, Z. H., Aziz, A. A., \& Zaharim, A. (2011). Lesson Study: Assessing Pre-Service Teacher's Performance of Teaching Chemistry. Engineering Education (ICEED), Proceedings of the 3rd International Congress, 208-213.

Teacher Education Division, Ministry of Education, Malaysia. (2011). Lesson Study: Learning through teacher collaborative practice. Book 1.

\section{Copyrights}

Copyright for this article is retained by the author(s), with first publication rights granted to the journal.

This is an open-access article distributed under the terms and conditions of the Creative Commons Attribution license (http://creativecommons.org/licenses/by/3.0/). 